\title{
RANCANG BANGUN WEBSITE SISTEM INFORMASI SUPPLY CHAIN MANAJEMEN PADA BISNIS PERGURUAN TINGGI
}

\author{
Ana Rohmah zaidah ${ }^{1}$, Achmad Fauzi Saputra ${ }^{2}$, Yusuf Amrozi ${ }^{3}$ \\ $1,2,3$ \\ Fakultas Sains dan Teknologi, UIN Sunan Ampel Surabaya
}

anarohmahzaidah77@gmail.com, saputrafauzi1999@gmail.com, yusuf.amrozi@uinsby.ac.id

\begin{abstract}
Indonesia as a developing country has made an agreement to take part in the process of reducing the impact of global warming and environmental issues, including waste problems. With the Green Campus program, the government supports all academics to care about this process. This is realized through the integration of science such as Supply Chain Management with information systems that focus on university business processes, one of which is a waste bank, which will later designate a university waste bank information system. This design uses the waterfall method with a series of analysis, design, implementation, testing and maintenance. It is hoped that this research will be able to provide suggestions for the design process for supply chain management in higher education businesses.
\end{abstract}

\section{Keywords: Supply Chain Management, Waste, University, Waterfall}

\section{PENDAHULUAN}

Indonesia telah mensepakati untuk turut andil dalam mengurangi dampak pemanasan global dan isu lingkungan. Permasalahan lingkungan yang menjadi isu terbesar adalah masalah sampah, Sebagai salah satu upayanya mengajak civitas akademik perguruan tinggi. Pemerintah telah menetapkan 5 perguruan tinggi pada tahun 2013 sebagai kampus percontohan, untuk program green campus, yaitu gerakan yang dilakukan kampus dari Negara maju atau berkembang untuk mengurangi pemanasan global dan isu lingkungan. Penerapan program Green campus tidak mudah, manajemen kampus serta mahasiswa perlu berkerja sama untuk mewujudkan program tersebut.Berdasarkan penelitian yang dilakukan Institut Teknologi Nasional dan Universitas katolik parahyangan, penyebab kurang optimalnya penerapan green kampus adalah kurangnya optimalnya kebijakan yang di buat manajemen kampus terhadap penerapan green campus. Integrasi antara konsep green campus dengan manajemen kebijakan campus dirasa perlu, salah satu hal yang bisa dilakukan dengan menggabungkan manajemen supply chain bisnis perguruan tinggi dengan konsep green campus. Supply Chain Manajemen atau manajemen rantai pasok merupakan proses bisnis berupa kolaborasi antara mitra rantai pasok dalam menyediakan produk, jasa, dan informasi untuk meningkatkan kinerja perusahaan dan memberikan nilai tambahan ke pelanggan dan pemangku kepentingan lainya (Purnomo \& Widianingsih, 2012). Sedangkan Supply Chain management peda penelitian ini mengintegrasikan pengolahan rantai pasok dengan pemikiran penyelamatan lingkungan, yang meliputi proses perancangan dan pengembangan produk, seleksi pemasok dan proses pengadaan (procurement), proses manufaktur dengan teknologi, distribusi dan dan daur ulang (Agustino, 2015). Pada penelitian Supply Chain manajemen Perguruan tinggi tentu memiliki unit kegitan mahasiswa di bidang bisnis yang di kelolah langsung oleh mahasiswa maupun dosen, salah satunya bank sampah/ pengolahan sampah pada perguruan tinggi dalam penerapanya optimalisasi pengolahan sampah perlu di dukung dengan kebijakan perguruan tinggi tentang manajemen rantai pasok dan informasi terkait dengan pengolahannya kepada semua civitas akademika. Supply chain manajement yang di integrasikan dengan sistem informasi pada pengolahan sampah akan berdampak pada pelestarian dan pengolahan sampah sehingga terwujudnya implementasi green campus. Penelitian yang dilakukan mempunyai tujuan :1) untuk memaksimalkan pengolahan sampah di instansi perguruan tinggi, 2) merancang sistem informasi terkait pengolahan sampah 3) mengintegrasikan sistem informasi pengolahan 
sampah dengan green supply chain. Penelitian ini menggunakan metode pengembangan sistem, sedangkan untuk proses perancangannya menggunakan metode waterfall.

\section{KAJIAN LITERATUR Waterfall}

Menurut (Bassil, 2012) model waterfall SDLC adalah proses pengembangan perangkat lunak berurutan dimana perkembangan dianggap mengalir semakin ke bawah (mirip dengan air terjun) melalui indeks fase yang harus dijalankan agar berhasil merangkai perangkat lunak computer. Pada dasarnya model waterfall memiliki fase : analisis, desain,implementasi, pengujian, dan pemeliharaan.

\section{Website}

Website merupakan sekumpulan halaman pada suatu domain di internet yang dibuat untuk tujuan tertentu yang saling berhubungan serta dapat diakses secara luas melalui home page dengan sebuah browser yang menggunakan URL website. Unsur-unsur pada website ada 3 yaitu sebagai berikut:

\section{Domain}

Website itu diibaratkan sebagai produk dan domain sebagai merk. Penggunaan domain yang menarik akan membuat pengguna internet tertarik untuk memasuki suatu website. Tentunya pemilihan nama domain yang unik agar mudah diingat untuk nantinya dikunjungi kembali.

\section{Hosting}

Hosting memiliki peran untuk menyimpan semua database (script, gambar, video, teks dan lain sebagainya) yang diperlukan untuk membentuk suatu website.

\section{Konten}

Konten pada website dapat berupa teks, gambar atau video. Jika dilihat dari konten yang disuguhkan, terdapat beberapa macam website. Misalnya saja, sosial media, website berita, website jual beli atau website yang berisi konten yang berdasarkan minat, bakat dan hobi.

\section{Manajemen Rantai Pasok}

Manajemen rantai pasok adalah pengelolaan dan pengawasan rantai siklus, mulai dari aliran material/ barang mentah, pembayaran, informasi dari pemasok ke produsen, ke pedagang grosir hingga pengecer sampai konsumen. Rantai pasokan adalah jaringan fisiknya, semua perusahaan yang berperan dalam memasok bahan baku, memproduksi barang, hingga mengirimkannya ke pengguna akhir. Manajemen rantai pasokan/ supply adalah sebuah metode, alat, atau pendekatan pengelolaannya. Menurut (Fitzsimmons \& Fitzsimmons, 1994), Manajemen Rantai Pasok adalah sebuah sistem pendekatan total untuk mengantarkan produk ke konsumen akhir dengan menggunakan teknologi informasi dalam mengkoordinasikan semua elemen supply chain dari mulai pemasok ke pengecer.

Komponen-komponen manajemen rantai pasok sebagai berikut:

\section{Upstream Supply Chain}

Upstream supply chain manajemen: Mengurus hubungan antara perusahaan dengan vendor atau pihak lain dalam hal transfer barang. Jadi barangbarang yang diproduksi oleh perusahaan tidak langsung sampai ke tangan konsumen tapi disalurkan ke perusahaan penyalur lainnya.

Misalnya sebuah perusahaan yang memproduksi smartphone. Produk smartphone ini tidak sertamerta sampai ke tangan konsumen langsung, tapi pihak manufacturer akan mengirimkan produknya ke supllier.

\section{Downstream Supply Chain}

Downstream supply chain mangement: Manajemen yang mengurusi transfer barang dari perusahaan langsung ke konsumen. Jadi kalau upstream supply chain harus lewat supplier dulu, maka downstream langsung bisa dibeli oleh konsumen.

Contoh: management ini yaitu mebel atau gallery art. Jadi mereka membuat produk langsung sesuai keinginan konsumen.

\section{Internal Supply Chain}

Internal supply chain management: Berkaitan dengan aktifitas pemasukan barang. Dalam hal ini yang kerap diperhatikan yaitu manajemen produksi, pabrikasi, dan juga kontrol ketersediaan bahan baku.

\section{Unified Modelling Language}

Unified Modelling Language merupakan suatu 
metode permodelan secara visual untuk sarana perancangan sistem berorientasi objek atau sebagai suatu bahasa yang sudah menjadi standar pada visualisasi, perancangan dan juga pendokumentasian sistem perangkat lunak(Bell, 2003).

Untuk mendapatkan banyak pandangan terhadap sistem informasi yang akan dibangun, UML (Unified Modelling Language) menyediakan beberapa diagram diantanya sebagai berikut:

\section{Use case diagram}

Use Case adalah teknik yang digunakan dalam pengembangan sebuah sistem informas untuk menangkap kebutuhan fungsional dari sistem yang berkesinambungan.

\section{Activity diagram}

Activity Diagram merupakan diagram yang menggambarkan aktivitas dari sebuah sistem atau proses bisnis

\section{Sequence diagram}

Diagram yang menggambarkan kolaborasi

dinamis antara sejumlah object. Kegunaannya

untuk menunjukkan rangkaian pesan yang

dikirim antara object juga interaksi antara object.

\section{METODE PENELITIAN}

Metode rekayasa perangkat lunak yang digunakan adalah dengan pendekatan terstruktur atau waterfall, sehingga perancangan pada penelitian ini menggunakan pendektana terstruktur, sehingga perancangan pada penelitian ini menggunakan notasi DFD (Data Flow Diagram), ERD (Entitiy Relationship Diagram), serta konseptual Database dengan tahapan berikut ini :

\section{Pengumpulan data}

Data yang digunakan dalam penelitian di dapat dari obsservasi dan wawancara dengan pengurus pusat bisnis bank sampah kampus.

\section{Studi literatur}

Proses dilakukan dengan mengumpulkan materi yang bersumber dari jurnal serta tanggapan dari parktisi dan professional mengenai perancangan dan pembangunan sistem informasi.

\section{Penerapan Supply Chain manajemen}

Tahapan ini sistem akan di sesuaian dengan konsep Green Supply Chain

Pembuatan Rancangan Alur Sistem Sebelum melakukan tahap implementasi, terlebih dahulu dibuat rancangan dari sistem informasi yang akan dibangun. Perancangan alur sistem dibuat dengan menganalisa aktivitas manual yang ada melalui desain flow chart, kemudian dikembangkan dengan perancangan alur yang terkompterisasi melalui Data Flow Diagram (DFD).

Perancangan Database. Selain merancang alur dari sistem informasi yang akan dibangun, sebelum tahap implementasi juga akan dirancang struktur penyimpanan data dan informasi nya yaitu database. Perancangan database diperlukan agar nantinya dapat menghasilkan database yang baik dan sesuai dengan kebutuhan sistem.

\section{Perancangan User Interface}

User interface adalah sebuah media yang berfungsi menghubungkan pengguna dengan sistem. Pada tahap ini user interface dirancang agar pengguna dapat cepat menguasai cara penggunaan sistem, interaktif, tidak membosankan, serta dapat menjaga emosi pengguna.

\section{PEMBAHASAN}

Flowchart

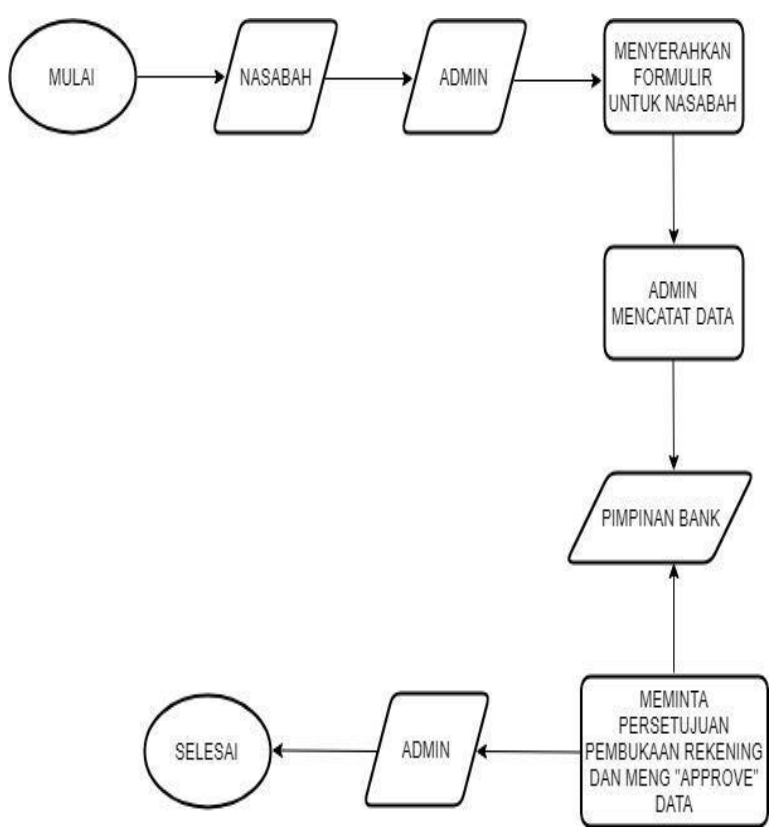

Gambar 1. Flowchart Sistem 


\section{Context Diagram}

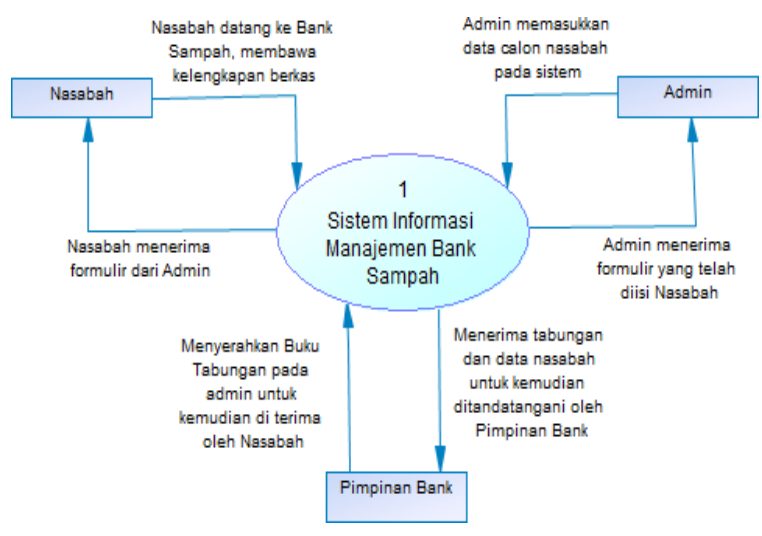

Gambar 2 Context Diagram

\section{Data Flow Diagram level 1}

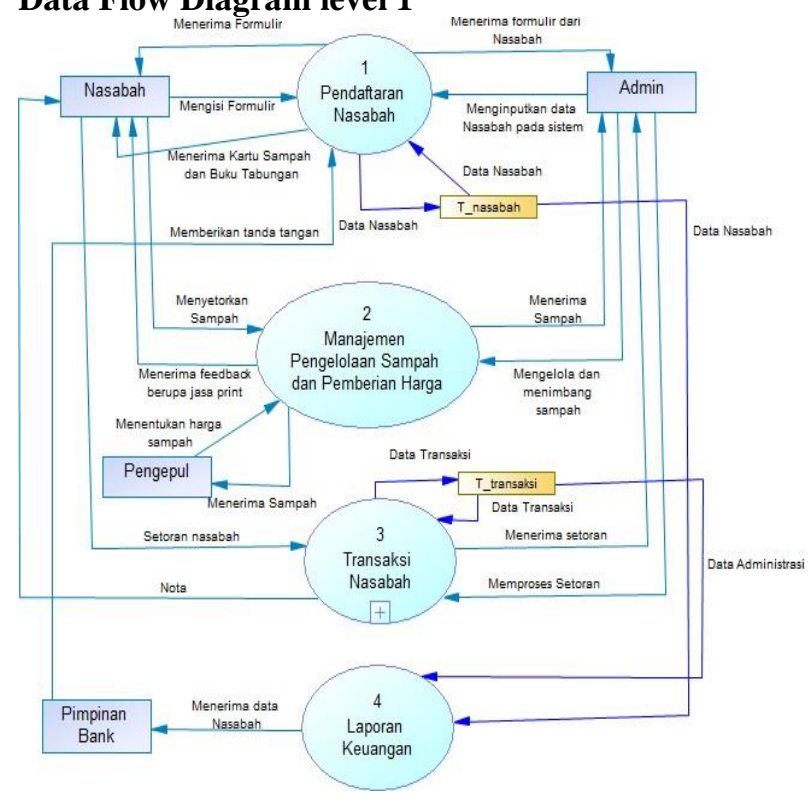

Gambar 3. DFD level 1

\section{Data Flow Diagram level 2}

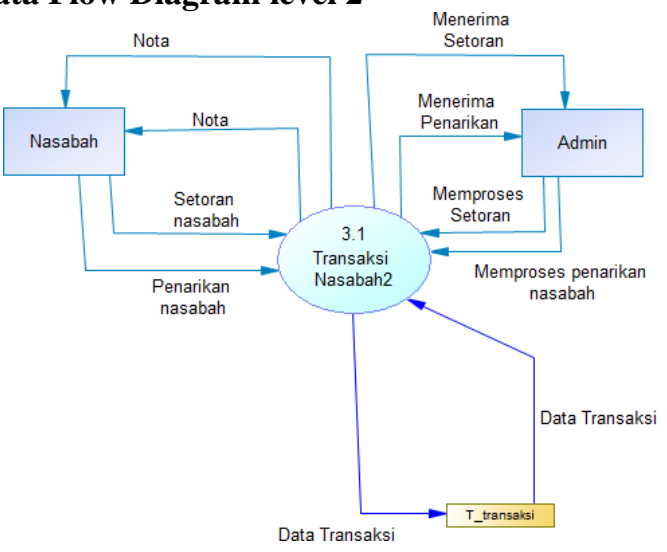

Gambar 4. DFD level 2

\section{Entity Relationship Diagram Conceptual}

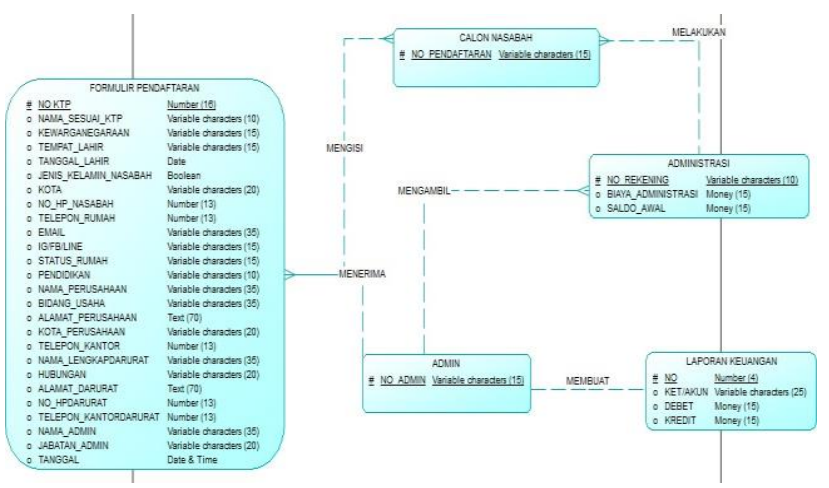

Gambar 5. Diagram Conceptual

\section{Entity Relationship Diagram Physical}

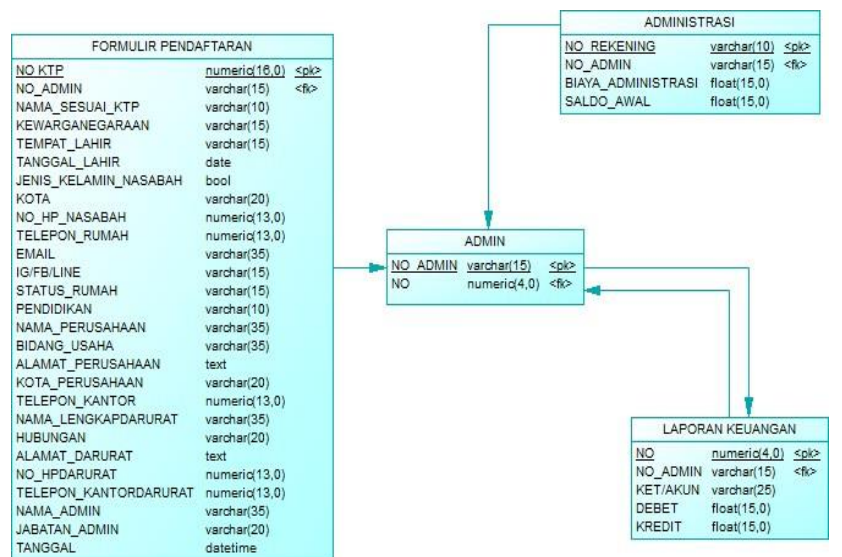

Gambar 6. Relationship Diagram Physical 
Tampilan User Interface

Tampilan dasbord

a BANK SAMPAH SYARIAH

Heme Masuk. Temanis

\section{$\sqrt{1000}$}

TUJUAN DAN

MANFAAT BANK

SAMPAH

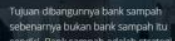

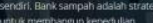

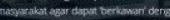

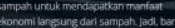

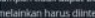

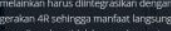

Gambar 7. Diagram Physical

Pendaftaran Member

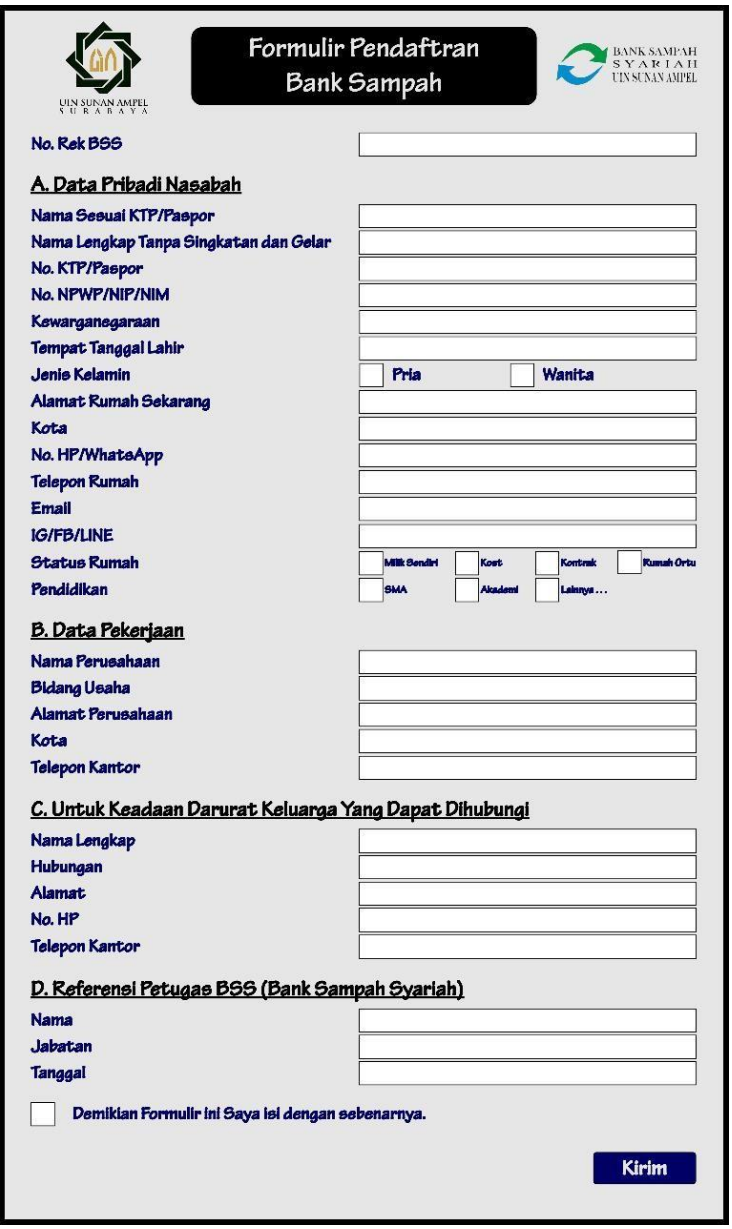

Transaksi Nasabah

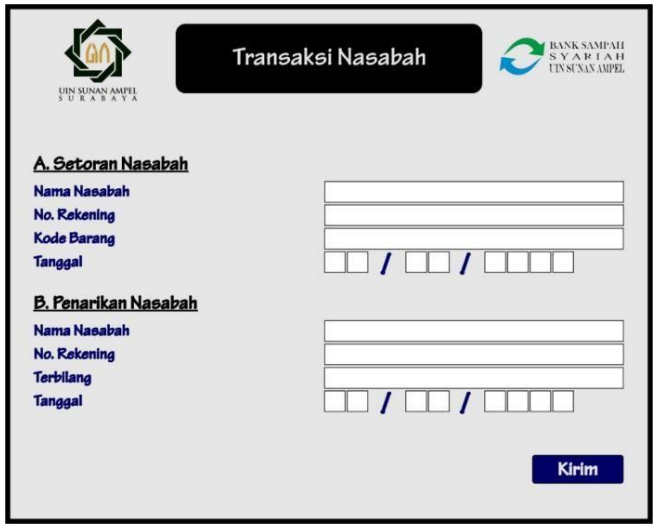

\section{Penggunaan Jasa Print Ijarah}

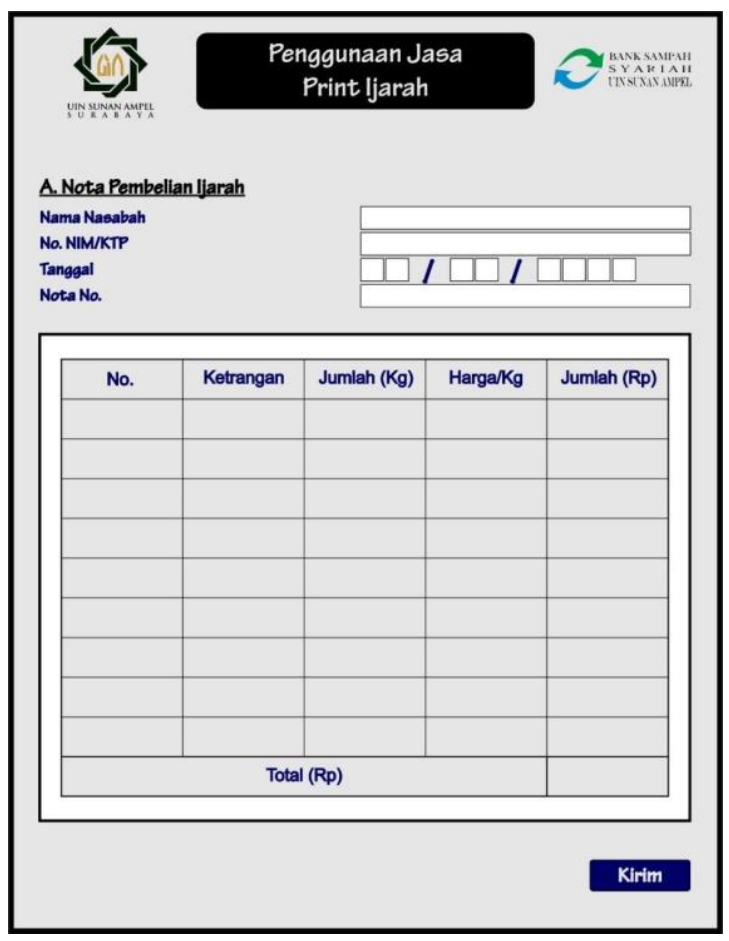

\section{KESIMPULAN}

Penerapan supply chain manajement dapat diintegrasikan dengan proses bisnis perguruan tinggi dalam menaggulangi pemanasalan global dan 
permasalahan lingkungan, salah satunyan penerapaan sistem informasi berbasis website yang memudahkan masyarakat atau civitas akademik untuk turut andil dalam aspek proses Green Campus. Sehingga diharapkan perancangan website sistem informasi bank sampah, dapat menimbulkan antusias dalam proses integrasi ilmu khususnya supply chain manajement dan teknologi.

\section{DAFTAR PUSTAKA}

[1]. Agustino, D. P. (2015). Perancangan Supply Chain Management Pada Sistem Pengelolaan Mice (Meetings Incentives Conferences Exhibitions) Di STMIK STIKOM Bali. Proceedings Konferensi Nasional Sistem Dan Informatika (KNS\&I).

[2]. Bassil, Y. (2012). A simulation model for the waterfall software development life cycle. ArXiv Preprint ArXiv:1205.6904.
[3]. Bell, D. (2003). UML basics: An introduction to the Unified Modeling Language. The Rational Edge.

[4]. Fitzsimmons, J. A., \& Fitzsimmons, M. J. (1994).

[5]. Service management for competitive advantage. McGraw-Hill New York, NY.

[6]. Purnomo, P. K., \& Widianingsih, L. P. (2012).

[7]. The influence of environmental performance on financial performance with corporate social responsibility (CSR) disclosure as a moderating variable: Evidence from listed companies in Indonesia. Review of Integrative Business and Economics Research, 1(1), 57. 